\title{
Research on build exercises that integrate knowledge to solve practical problems in teaching high school students
}

\author{
Le Thi Thu Trang ${ }^{1}$, Nguyen Thi $\mathrm{Na}^{2}$, Hoang Thi Lanh ${ }^{3}$, Van Hung Mai ${ }^{4 *}$ \\ Corresponding Email: hungmv@vnu.edu.vn \\ ${ }^{1}$ Ngo Quyen High School, Ha Long, Quang Ninh, Vietnam \\ ${ }^{2}$ Me Linh High School, Dong Hung, Thai Binh, Vietnam \\ ${ }^{3}$ Gia Vien A High School, Gia Vien, Ninh Binh, Vietnam \\ ${ }^{4}$ VNU University of Education, Cau Giay, Hanoi, Vietnam
}

Received: August 3, 2021

Revised: August 24, 2021

Accepted: September 8, 2021

\begin{abstract}
Based on one of the viewpoints of building the Biology curriculum, which is integrated education and sustainable development education, helps students strengthen and develop the competency to mobilize and apply integrated knowledge, skills in many different fields to effectively solve problems in study and their' life. Practical problems in teaching Biology are very diverse, associated with daily life and related to other subjects such as environmental protection, health care, response to the Covid-19 epidemic. The article proposes the process of designing and using integrated practice exercises in teaching Biology in high school in order to develop students' competency to solve practical problems.
\end{abstract}

Keywords: Exercise, Integration, Practice, Biology

\section{Introduction}

In teaching, it is necessary to focus on forming and developing students not only knowledge of a subject but also need to orient and promote the best competency of each student who can apply knowledge and skills of other subjects. learning in solving practical problems is important and necessary nowadays.

In the current teaching practice in high schools, most teachers also focus on imparting singlesubject theoretical knowledge to students in the direction of content approach but less in the direction of competency approach, especially is the competency to solve practical problems, that is, students need to have the competency to know how to do, to know "learning with practice", "associating theory with practice" (Bridgers et al., 2020 ;Grant \& Baden-Fuller, 2018; Sönmez, 2017). Furthermore, Hasib et al., (2021) suggest that it is considerably matter for the teacher to selectively choose how students should be treated.

Moreover, Content knowledge and assessment often use questions and exercises predefined in the textbook program, so students have little access to current and urgent practical issues today. Therefore, students often have a heavy memory in terms of exam-related knowledge but are less interested in practical issues around themselves such as health issues, environmental protection, disease prevention or students have attitudes of dependence, indifference, indifference, dependence on family, school and society.

\section{Overview}

In Vietnam in recent years, there have been studies on practical integrate exercises to develop students' competency to apply knowledge in single-subject form such as "Designing practical exercises in teaching Biology 11 in high school" (Oai, 2016) and "The process of designing and 
using practical exercises to develop the competency to apply knowledge for students in teaching the chapter Metabolism of matter and bio-energy 11" (Bao \& Hoa, 2020), however, more research is still needed on integration exercises, linking subject knowledge with practice for students. Therefore, the article introduces the concept, role, process of designing and using integrated practice exercises to develop practical problem-solving capacity in teaching Biology in high school.

The research works of the authors just stop at using exercises, practical exercises in teaching single subjects to train learners' competency to apply that subject knowledge and skills into practice. Through the research, no author has mentioned the integration exercise between the knowledge of the subjects related to the current and urgent practical context in teaching Biology.

Based on the above concepts of Exercises, Practices, and Practices, the authors propose to build the concept of Practice-Integrated Exercises as follows: Practical-Integrated Exercises are exercises derived from Practical situations related to the content of knowledge of different subjects are assigned to students to perform. Practical integration exercises in teaching Biology is a type of exercise related to the content of the Biology subject program and integrated and connected with other related subjects to help students mobilize and synthesize knowledge to solve practical problems.

According to Trung \& Hoi (2016), the problem-solving capacity consists of four components, which are: Problem detection skills; Skills to establish space and form scientific hypothesis; Competency to plan and conduct problem solving; Competency to evaluate solutions and selfcorrection.

Based on the criteria for assessing problem-solving capacity of Le Dinh Trung, to design, build and use practical integrated exercises in teaching Biology towards developing practical problem-solving capacity, the authors have developed the criteria of practical problem-solving capacity as follows:

Table 1. Criteria of practical problem-solving capacity

\begin{tabular}{|l|l|l|}
\hline No & \multicolumn{1}{|c|}{ Criteria } & \multicolumn{1}{|c|}{ Display indication } \\
\hline 1 & Finding problems in life & $\begin{array}{l}\text { Students discover and identify information and data } \\
\text { related to practical problems. }\end{array}$ \\
\hline 2 & $\begin{array}{l}\text { Understanding practical } \\
\text { problems by integrating } \\
\text { subjects }\end{array}$ & $\begin{array}{l}\text { Students identify knowledge of subjects related to } \\
\text { practical problems, analyze, interpret and clarify } \\
\text { information and data related to practical problems. }\end{array}$ \\
\hline 3 & $\begin{array}{l}\text { Apply knowledge and skills } \\
\text { in Biology with other } \\
\text { subjects to solve practical } \\
\text { problems }\end{array}$ & $\begin{array}{l}\text { Students apply and use the knowledge and skills } \\
\text { learned to solve practical problems. }\end{array}$ \\
\hline 4 & $\begin{array}{l}\text { To Assessment your } \\
\text { competency to solve } \\
\text { practical problems }\end{array}$ & $\begin{array}{l}\text { Students evaluate the results, the level achieved after } \\
\text { solving practical problems. }\end{array}$ \\
\hline
\end{tabular}

Research the theoretical basis from which to build exercises that integrate knowledge to solve practical problems in teaching biology to help students develop their competency to solve practical problems.

\section{Methods}

Theoretical research method: On the basis of analyzing information from relevant documents to build a theoretical basis for the research problem. Survey method: Using questionnaires and multiple-choice tests to survey teachers and students, thereby recognizing the reality of using 
Exercises in teaching Biology and the competence to solve students' practical problems. Method of consultation: Through in-depth interview questions with education experts to find out specialized information related to the research problem. Information processing methods: Using the computer software SPSS 20.0 to analyze and process information and obtained results

\section{Results and Discussion}

\section{The role of integrated exercises associated with practice}

Practice-integrated exercises are tools for teachers to innovate, test and evaluate in the direction of forming and developing students' quality and comprehensive competence, especially the competency to solve practical problems.

Practice-integrated exercises help students enhance self-control, self-study, creativity, explore integrative knowledge on learning media tools such as Internet, books, magazines... to complete in learning activities in class or at home.

\section{The process of building exercises associated with practice}

The design process of the integrative exercise includes the following steps:

Step 1: Identify the core knowledge content of the topic

Identify and analyze the knowledge content circuit of the topic to mobilize the synthesis of knowledge and skills of Integrated Biology subject with other subjects for the design of Practical Integrated Exercises.

\section{Step 2: Select practical problems related to knowledge}

Selecting topical practical problems creates opportunities for students to mobilize and synthesize their knowledge of Biology and other related subject knowledge to solve practical problems.

Step 3: Design integrated exercises associated with practice for students.

Use tools such as questions and exercises in the form of essays, multiple choice tests on exercise sheets, or product reports presented on posters, power point, etc., or STEM models, which are related to the content of knowledge. Biology subject and integrate other subject knowledge content suitable to the lesson or topic to design practical integration exercises according to the criteria of practical problem-solving capacity for students.

Step 4: Complete and require integration exercises oriented to develop students' practical problem-solving capacity.

Check and standardize the questions in the practical integrated exercises, then assign the exercises and ask students to follow the suggestions and criteria given.

Depending on the students, the conditions of facilities for teaching, the actual context, the teacher may ask students or groups of students to complete practical exercises in the form of answering questions, submitting products in the form of models, posters, paper reports, power point and etc...

\section{The integrated topics associated with practice in teaching Biology}

Table 2. Topic 1: Viruses and infectious diseases (Biology 10)

Currently, infectious diseases in general and infectious diseases caused by viruses are seriously affecting human health and life. Typically, the global Covid-19 pandemic has been threatening human health and life, affecting the economy, production, culture and society in countries. Understanding the virus as well as how to prevent infectious diseases is essential, 


\begin{tabular}{|l|l|}
\hline $\begin{array}{l}\text { helping students have basic knowledge to protect themselves, their families and the } \\
\text { community. }\end{array}$ \\
\hline \multicolumn{2}{|c|}{ Integration of practical problem solving } \\
\hline Finding problems in life & $\begin{array}{l}\text { The issue of taking care of and protecting the health } \\
\text { of yourself and the community before the Covid-19 } \\
\text { pandemic }\end{array}$ \\
\hline $\begin{array}{l}\text { Understanding practical problems by } \\
\text { integrating subjects }\end{array}$ & $\begin{array}{l}\text { Biology: Understanding Covid 19: origin, } \\
\text { transmission route, prevention methods, fast- } \\
\text { spreading virus strains such as: Delta.... } \\
\text { Integrated subjects: Mathematics (using numbers, } \\
\text { statistics of Covid -19 cases, deaths, number of } \\
\text { cured cases, ....), Literature (writing stories), music } \\
\text { (composition) songs), Fine arts (painting), } \\
\text { informatics (design propaganda posters, slogans, } \\
\text { posters..), Scientific research (scientific reports } \\
\text { investigating the current situation and measures to } \\
\text { raise awareness. ). }\end{array}$ \\
\hline $\begin{array}{l}\text { Apply knowledge and skills in Biology } \\
\text { with other subjects to solve practical } \\
\text { problems }\end{array}$ & $\begin{array}{l}\text { Explain the harms and dangers from which there is } \\
\text { a sense of prevention. } \\
\text { Students can choose the following forms of } \\
\text { expression: composing stories, composing songs, } \\
\text { drawing pictures, designing videos, writing essays } \\
\text { or scientific reports to investigate the current } \\
\text { situation and measures to raise awareness. }\end{array}$ \\
\hline $\begin{array}{l}\text { To assessment your competency to } \\
\text { solve practical problems }\end{array}$ & $\begin{array}{l}\text { Self-assess your competency to solve practical } \\
\text { problems and give suggestions to your students } \\
\text { about their learning products in terms of aesthetics, } \\
\text { reliability, accuracy, presentation competency. }\end{array}$ \\
\hline
\end{tabular}

Table 3. Topic 2: Individuals and populations of organisms (Biology 12)

Content 1: A farmer in Thai Binh, on a trip to Dalat, saw many beautiful flowers. This farmer bought some flowers (roses, lilies, lavender etc...) to plant in Thai Binh. What do you think the results of planting these flowers in Thai Binh will be? Explain.

Content 2: When randomly catching a fish species in three different regions, the proportions of fish species by age in each region are as follows:

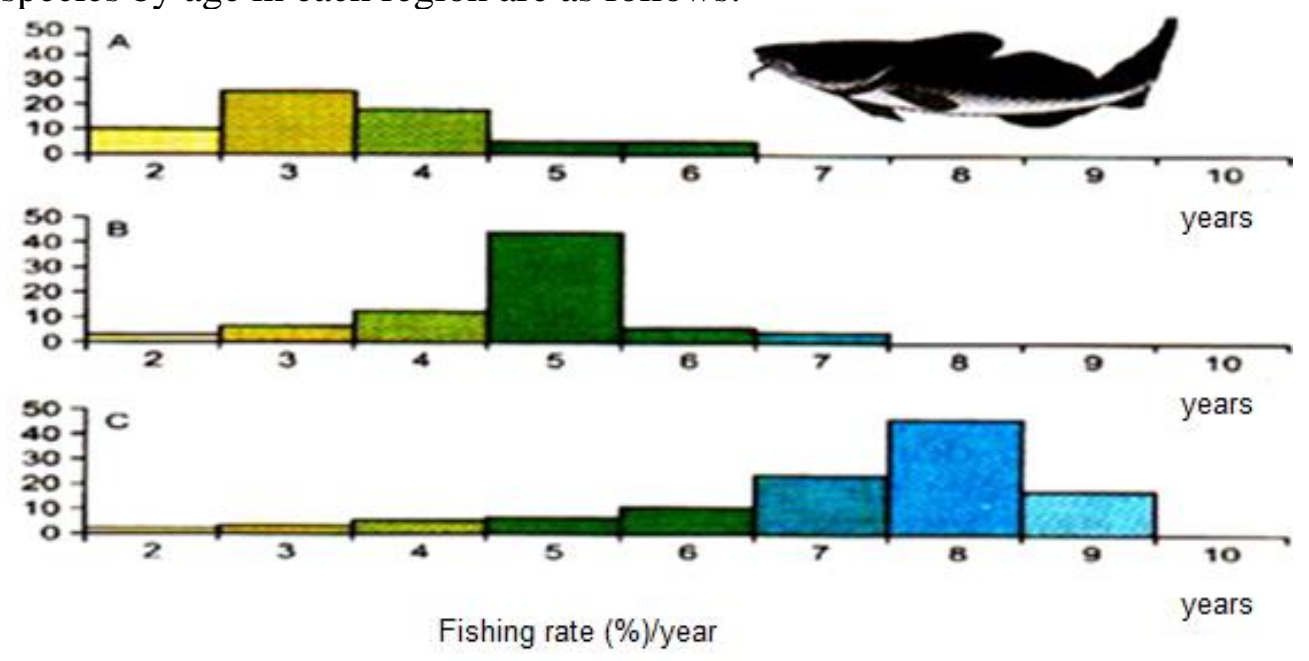

Are the following statements true or false? Please explain?

(1) The population in area $\mathrm{A}$ is having the highest individual density of the three regions. 


\begin{tabular}{|l|l|}
\hline $\begin{array}{l}\text { (2) Area B is being reasonably exploited. } \\
\text { (3) The population in region C is experiencing the fastest growth in population size. }\end{array}$ \\
\hline \multicolumn{2}{|c|}{ Integration of practical problem solving } \\
\hline Finding problems in life & $\begin{array}{l}\text { Practical issues: Exploiting plant varieties suitable to } \\
\text { the ecological environment, rational exploitation of } \\
\text { aquatic products. }\end{array}$ \\
\hline $\begin{array}{l}\text { Understanding practical problems } \\
\text { by integrating subjects }\end{array}$ & $\begin{array}{l}\text { Biology: animal breeds and plants, basic } \\
\text { characteristics of biological populations (sex ratio, } \\
\text { density, age group structure, population growth...) } \\
\text { Geography: Climatic, geological and natural } \\
\text { conditions in 2 places: Da Lat and Thai Binh. } \\
\text { Knowledge of agrotechnical subjects: Flower care } \\
\text { techniques suitable for species and regions. }\end{array}$ \\
\hline $\begin{array}{l}\text { Apply knowledge and skills in } \\
\text { Biology with other subjects to solve } \\
\text { practical problems }\end{array}$ & $\begin{array}{l}\text { Integrate subject knowledge and practice to provide } \\
\text { practical analysis and interpretation. }\end{array}$ \\
\hline $\begin{array}{l}\text { To assessment your competency to } \\
\text { solve practical problems }\end{array}$ & $\begin{array}{l}\text { Students self-assess themselves by answering } \\
\text { questions and thereby have the attitude to apply } \\
\text { knowledge to practical problems of production and } \\
\text { labor. }\end{array}$ \\
\hline
\end{tabular}

\section{Conclusion}

The integrated exercise to solve real-world problems is actually the application of knowledge into practice with the participation of many related subjects, each exercise is a topic that acts as a topic. science in teaching students. Integration exercises play a role in developing students' competency to solve practical problems to meet the goal of forming and comprehensively developing students' qualities and competencies in line with the teaching orientation. according to the General Education Program 2018. The use of integrated exercises associated with practice in teaching Biology helps students approach and get close to real life problems that are happening every day and apply the knowledge and skills they have learned. in solving practical problems of self, family and social community such as: health protection, disease prevention, environmental protection, socio-economic development... competency to solve practical problems for students, helping students to "learn with practice", "theory associated with practice".

\section{References}

Bao, D. Q. \& Hoa, P. T. M. (2020). The process of designing and using practical exercises to develop students' ability to apply knowledge in teaching the chapter on Transformation of matter and energy Biology 11. Journal of Education (477).

Bridgers, S., Jara-Ettinger, J., \& Gweon, H. (2020). Young children consider the expected utility of others' learning to decide what to teach. Nature human behaviour, 4(2), 144152 .

Grant, R. M., \& Baden-Fuller, C. (2018). How to develop strategic management competency: Reconsidering the learning goals and knowledge requirements of the core strategy course. Academy of Management Learning \& Education, 17(3), 322-338.

Hasib, M., Yassi, A. H., \& Nasmilah, N. (2021). Learner and Instructor's Perception on Discussion Technique in ELT. Journal Educational Verkenning, 2(1), 1-7.

Ministry of Education and Training (2018), General Education Program - Master Program, Hanoi Publishing House. 
Ministry of Education and Training (2018), General Education Program in Biology, Hanoi Publishing House.

Oai, L. T. (2016). Design practical exercises in teaching Biology 11 high schools. Education Journal, (396), 52-55.

Sönmez, V. (2017). Association of Cognitive, Affective, Psychomotor and Intuitive Domains in Education, Sönmez Model. Universal Journal of Educational Research, 5(3), 347-356.

Trung, L. D., \& Hoi, P. T. T. (2016). Teaching in the direction of forming and developing learners' capacity in high schools. National University of Education Publishing House. 